\title{
Electroanalgesia for the postoperative control pain in dogs
}

\author{
Eletroanalgesia para o controle da dor pós-operatória em cães
}

\begin{abstract}
Renata Navarro Cassu', Daniele Alves da Silva", Túlio Genari Filho"I, Helaine Stevanin ${ }^{\text {III }}$
${ }^{\mathrm{I}} \mathrm{PhD}$, Full Professor, Department of Veterinary Surgery and Anestesiology, Scholl of Veterinary Medicine, Unoeste, Presidente Prudente-SP, Brazil. Mentor. Responsible for intelectual, scientific content, statistical analysis of the study and critical revision.

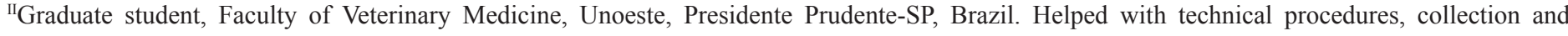
processing of study informations.

IIIFull Professor, Department of Veterinary Surgery and Anestesiology, Scholl of Veterinary Medicine, Unoeste, Presidente Prudente-SP, Brazil. Responsible for surgical procedure.
\end{abstract}

\begin{abstract}
PURPOSE: To evaluate the analgesic and neuroendocrine effects of electroanalgesia in dogs undergoing ovariohysterectomy.

METHODS: Eighteen dogs were randomly distributed to three groups of six animals each and received either electrical stimuli at acupuncture points (EA), at peri-incisional dermatomes (DER) and at both acupuncture points and peri-incisional dermatomes (EAD). Pre-anesthetic medication was acepromazine $\left(0.05 \mathrm{mg} \mathrm{kg}^{-1}\right.$, IV). Anesthesia was induced with propofol (4 to $5 \mathrm{mg} \mathrm{kg}^{-1}$, IV) and maintained with isoflurane. Postoperatively pain degree was measured using a numerical rating scale. Dogs were scored at 1, 3, 6, 12 and 24 hours postoperative. If the pain score was $\geq 6$, supplemental morphine $\left(0.5 \mathrm{mg} \mathrm{kg}^{-1}, \mathrm{IM}\right)$ was administered. Serum cortisol concentration was measured before pre-anesthetic medication (basal), and at 1, 12 and 24 hours postoperative.
\end{abstract}

RESULTS: EA and EAD- treated dogs had lower pain scores than DER treated dogs one hour postoperatively. Fewer EA and EADtreated dogs required rescue analgesia. Serum cortisol did not differ among treatments.

CONCLUSION: Preoperative application of electrical stimuli to acupuncture points isolated or in combination with periincisional dermatomes provides a reduced postoperative opioid requirement and promotes an effective analgesia in dogs undergoing ovariohyterectomy.

Key words: Electroacupuncture. Analgesia. Ovary. Hysterectomy. Salpingectomy. Dogs.

\section{RESUMO}

OBJETIVO: Avaliar os efeitos analgésicos e neuroendócrinos da eletroanalgesia em cadelas encaminhadas para ovariossalpingohisterectomia.

MÉTODOS: Foram avaliadas 18 cadelas, distribuídas aleatoriamente em três tratamentos de seis animais cada: aplicação de estímulo elétrico em pontos de acupuntura (EA), em dermátomos periincisionais (DER) e em pontos de acupuntura associados aos dermátomos periincisionais (EAD). Todos os animais foram tranquilizados com acepromazina $\left(0,05 \mathrm{mg} \mathrm{kg}^{-1}\right.$, IV), seguindo-se a indução com propofol (4 a 5mg kg-1, IV) e manutenção anestésica com isofluorano. O grau de analgesia foi avaliado 1, 3, 6, 12 e 24 horas após a cirurgia mediante escala descritiva numérica. Animais com escores $\geq 6$ receberam analgesia de resgate com morfina $\left(0,5 \mathrm{mg} \mathrm{kg}{ }^{-1}, \mathrm{IM}\right)$. A concentração sérica de cortisol foi avaliada antes da tranquilização, 1, 12 e 24 horas após a cirurgia.

RESULTADOS: Escores inferiores de dor foram observados nos tratamentos EA e EAD em relação ao DER na primeira hora pósoperatória. A analgesia de resgate foi menos requerida nos animais dos tratamentos EA e EAD. O cortisol não diferiu entre os tratamentos. CONCLUSÃO: A eletroestimulação de acupontos isolados ou associados aos dermátomos periincisionais reduz o requerimento pósoperatório de opioides, bem como confere efetiva analgesia para cadelas submetidas à ovariossalpingohisterectomia.

Descritores: Eletroacupuntura, Analgesia. Ovario. Histerectomia. Salpingectomia. Cães. 


\section{Introduction}

The use of electrical stimulation for pain control began many centuries ago. However, interest in electroanalgesia increased after pain physiology was better understood, as well as to the efforts of researchers interested in finding alternatives to the traditional opiate and non-opiate analgesic drugs ${ }^{1}$.

Several studies have shown that patients receiving electrical stimulation applied at the traditional Chinese acupoints (electroacupuncture) prior to surgery have a lower level of pain, reduced opioid requirement, a lower incidence of post-nausea and vomiting, and lower sympatho-adrenal responses ${ }^{2-6}$. In addition, other studies have demonstrated that the electrical stimulation applied at the dermatomal levels corresponding to the skin incision also reduces pain and postoperative opioide analgesic requirement ${ }^{7,8}$. However, better results have been published when the electrical stimulation was applied simultaneously at both the dermatome corresponding to the surgical incision and a classical Chinese acupoint ${ }^{9}$.

The purpose of this study was to evaluate the analgesic and neuroendocrine effects of electroacupunture, electrical stimulation at the peri-incisional dermatomes and electroacupunture plus electrical stimulation at the peri-incisional dermatomes in dogs undergoing ovariohysterectomy.

\section{Methods}

This study was approved by the Institutional Animal Research Ethical Committee (protocol number 107/06), and permission for participation of each dog was obtained from de owner. Eighteen healthy adult, crossbreed, female dogs, weighing 4.5 to $26 \mathrm{~kg}(11 \pm 12 \mathrm{~kg})$ were evaluated. The animals indicated for elective ovariohysterectomy were selected by physical examination and laboratorial tests (complete blood cell count, serum biochemistry).

After withdrawal of food and water for 12 and 3 hours, respectively, the animals underwent the same anesthesia protocol. All dogs were sedated with acepromazine $\left(0.05 \mathrm{mg} \mathrm{kg}^{-1}\right)$ administered intravenously (IV). Fifteen minutes after sedation, the dogs were randomly and equally distributed into three treatments: EA $(n=6)$ - The needles were introduced bilaterally into ST 36, SP 6 and GB 34 acupoints. An alternating square wave dense/disperse $0.2 \mathrm{~ms}$ continuous electrical stimulus was used $(3-200 \mathrm{~Hz})$. EA (Sikuro, DS100, Brazil) started with zero current and increased slowly until local muscle contractions were observed. DER $(n=6)$ - similar to the treatment described for EA, but with electrical stimulation applied at the dermatomal levels corresponding to the abdominal incision. The acupuncture needles were inserted longitudinally, covering a $4 \mathrm{~cm}$-area on both the right and left sides of the surgical incision, which was performed over the linea alba, under the umbilical scar. The same stimulus used in EA was applied, with the same duration. $\operatorname{EAD}(n=6)$ - the electrical stimuli were applied at the acupoints as described for EA treatment group, and at the dermatomal level as described for DER treatment group.

The electrical stimulation was applied for 45 minutes before induction of anesthesia. After that, anesthesia was induced with propofol (4 to $5 \mathrm{mg} \mathrm{kg}^{-1}$, IV). The trachea was intubated and anesthesia maintained with isoflurane under spontaneous ventilation using a partial rebreathing system with an oxygen flow of $1 \mathrm{~L}^{-1} \mathrm{~min}^{-1}$. Ringer's solution $\left(10 \mathrm{~mL} \mathrm{~kg}^{-1} \mathrm{~h}^{-1}\right)$ was infused intravenously by peristaltic infusion pump throughout the surgical procedure. All animals underwent routine ovariohysterectomy through a 2 to $3 \mathrm{~cm}$ midline incision by the same experienced surgeon.

During the first 24 hours postoperative, the animals underwent a blind evaluation of the analgesia degree using a numerical pain scale ${ }^{10-12}$, with postoperative measurements at 1,3 , 6, 12 and 24 hours postoperative. Pain scores were assigned, and the maximum possible scores obtained was 20 (Table 1). Scores of 0 to 5 indicated mild pain, scores of 6 to 9 indicated moderate pain, and scores of more than 10 indicated severe pain. Additional analgesia was given (intramuscular morphine at $0.5 \mathrm{mg} \mathrm{kg}^{-1}$ ) to dogs that scored 6 or more. 
TABLE 1 - Numerical pain scoring system applied to dogs after ovariohysterectomy.

\begin{tabular}{|c|c|c|}
\hline Observation & Criteria & Score \\
\hline \multirow{2}{*}{ Heart rate } & $11 \%-30 \%$ above preoperative value & 1 \\
\hline & $31 \%-50 \%$ above preoperative value & 2 \\
\hline \multirow{3}{*}{ Respiratory rate } & $</=10 \%$ above preoperative value & 0 \\
\hline & $11 \%-30 \%$ above preoperative value & 1 \\
\hline & $31 \%-50 \%$ above preoperative value & 2 \\
\hline \multirow{2}{*}{ Arterial blood pressure } & $31 \%-50 \%$ above preoperative value & 2 \\
\hline & $>50 \%$ above preoperative value & 3 \\
\hline \multirow{2}{*}{ Salivation } & Normal & 0 \\
\hline & Above normal & 1 \\
\hline \multirow{2}{*}{ Mydriasis } & No & 0 \\
\hline & Yes & 1 \\
\hline \multirow[t]{2}{*}{ Agitation } & Mild agitation & 1 \\
\hline & Moderate agitation & 2 \\
\hline \multirow{3}{*}{ Body position } & Severe agitation & 0 \\
\hline & Sternal and relaxed & 1 \\
\hline & Protecting the incision site, including lateral and fetal position & 2 \\
\hline \multirow{4}{*}{$\begin{array}{l}\text { Response to palpation } \\
\text { of the incision site }\end{array}$} & No response & 0 \\
\hline & Mild response, looks at incision site & 1 \\
\hline & Turns head for the incision site, mild vocalization & 2 \\
\hline & Turns head with intention to bite, severe vocalization & 3 \\
\hline
\end{tabular}


Venous blood samples were collected from the jugular vein to measure of cortisol before the pre-anesthetic medication was administered (basal), at 1, 12 and 24 hours postovariohysterectomy. Serum samples were stored at $-70 \mathrm{C}$ and analyzed within 12 months after collection. Cortisol levels were quantified using a solid-phase radioimmunoassay (Coat-A-Count Cortisol - DPC, California, USA).

The occurrence of adverse effects such as nausea, vomiting, tremors, excitement and drooling were also recorded.

Data were recorded as mean $\pm \mathrm{SD}$. The data analyzed using an analysis of variance with the F test followed by Tukey's test using Graphpad software. Differences between treatments at each time point, differences in time for each treatment, and the interaction between treatment and time were investigated. A p-value less than 0.05 was considered significant.

\section{Results}

There were no differences $(\mathrm{P}>0.05)$ between the groups in terms of mean surgical time $(37 \pm 3,39 \pm 8$ minutes and $32 \pm 8$ for the EA, DER and EAD groups, respectively), extubation time $(5 \pm 3,4.5 \pm 2$ and $6 \pm 8$ minutes for the EA, DER and EAD groups, respectively) and recovery time $(25 \pm 5,21 \pm 7$ minutes and $23 \pm 4$ for the EA, DER and EAD groups, respectively).

The median pain scores were significantly lower in the EA and EAD treatments when compared with DER treatment at first hour postoperative (Figure 1).

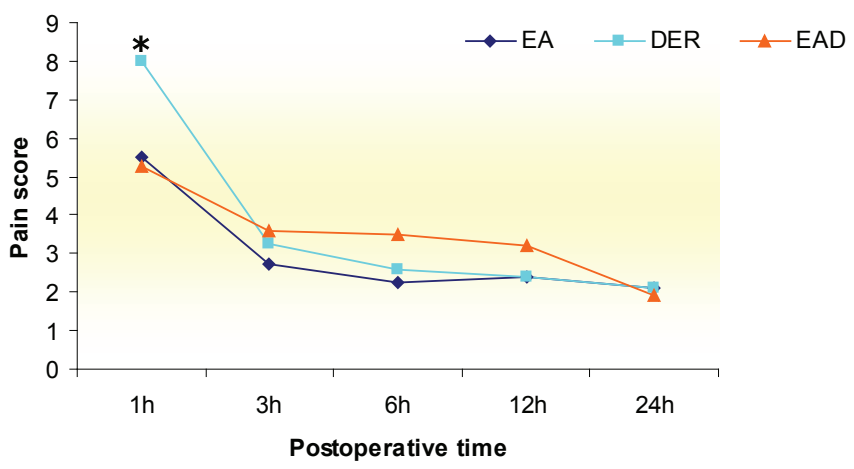

FIGURE 1 - Mean of pain score in dogs treated with electrical stimulation of acupoints ST36, SP6 and GB34 (EA, n=6), electrical stimulation at peri-incisional dermatomes (DER, $n=6)$ and electrical stimulation at acupoints ST36, SP6 and GB34 plus peri-incisional dermatomes (EAD, $\mathrm{n}=6$ ).

${ }^{*} \mathrm{P}<0.05$, significant increase when compared with EA and EAD treatments.

Two out of six dogs $(33.3 \%)$ in the EA and EAD groups and five out of six dogs $(83.3 \%)$ in the DER group required additional analgesia at first three hours postoperative (Figure 2).

Serum cortisol were significantly higher at one hour postoperative than baseline cortisol concentrations and returned to basal values at 24 hours postoperative (Figure 3 ).

Undesirable side effects were not observed in any of the dogs.

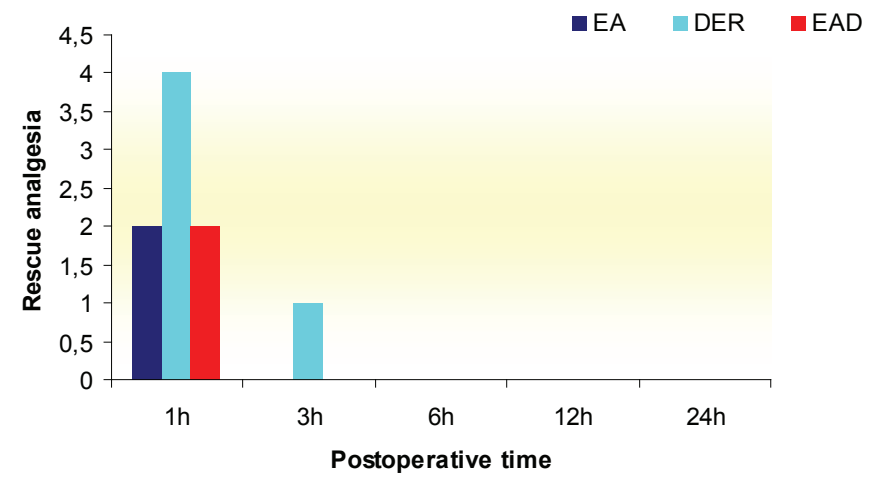

FIGURE 2 - Number of dogs that required rescue analgesia at postoperative time.

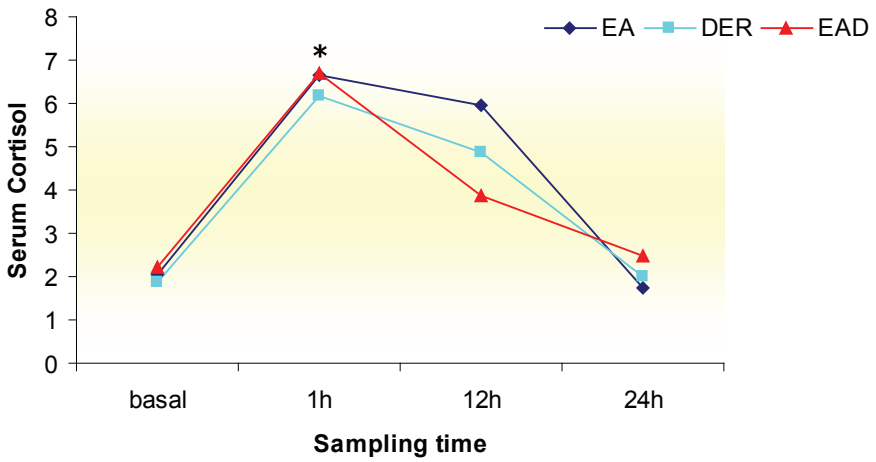

FIGURE 3 - Mean serum cortisol concentration $\left(\mu \mathrm{g} . \mathrm{dl}^{-1}\right)$ in dogs treated with electrical stimulation at acupoints ST36, SP6 and GB34 (EA, $\mathrm{n}=6$ ), electrical stimulation at peri-incisional dermatomes (DER, $\mathrm{n}=6$ ) and electrical stimulation at acupoints ST36, SP6 and GB34 plus periincisional dermatomes $(\mathrm{EAD}, \mathrm{n}=6)$.

$* \mathrm{P}<0.05$, significant increase when compared with the baseline values and with the 24 hours postoperative.

\section{Discussion}

The current study confirms previous reports in humans which have shown satisfactory postoperative analgesia following preoperative application of electrical stimulation at the traditional Chinese acupoints isolated ${ }^{2,4,5,13}$ or in combination with electrical stimulation at the dermatomal level of the skin incision ${ }^{8,9}$. In both groups (EA and EAD), the pain scores were lower at the first hour post-ovariohysterectomy when compared with DER treatment. Additionally, rescue analgesia was more frequent in DER treatment, while in EA and EAD treatments a few dogs needed 
supplemental analgesia, implying that both regimens provide adequate analgesia.

The mechanism by which acupuncture produces analgesia remains unclear". Some authors ${ }^{9,13,14}$ agree with the classic "gate control theory" 15 , which supports that the stimulus promoted by needles introduced intradermically can activate large nerve fibers (A $\beta$ fibers) and change pain perception in spinal cord ${ }^{4}$. There is evidence showing that acupuncture stimulates the pain inhibitory system at the spinal cord, brainstem and other areas of the central nervous system, such as thalamus, $3^{\text {rd }}$ ventricle, mesencephalon, diencephalon, hypothalamus and hypophysis. Endogenous opioids, such as endorphins, enkephalins and dynorphins also contribute to the analgesic effect of acupuncture ${ }^{16}$.

The acupoints selected in the present study have produced analgesia in several other studies ${ }^{5,14,19,20}$. According to Traditional Chinese Medicine, the ST36 acupoints are highly effective in relieving abdominal pain ${ }^{8}$. Additionally, the characteristics of the electrostimulation used also played an important analgesic role. The dense-disperse mode, with frequency ranging from 3 to $200 \mathrm{~Hz}$, promotes the release of different types of endogenous opiates. Application of low-frequency EA ( $2 \mathrm{~Hz})$ accelerates the central release of encephalin and $\beta$ endorphin, whereas EA at high frequency $(100 \mathrm{~Hz})$ induces dinorphin release by the spinal cord $^{21}$. Electroanalgesia techniques, such as transcutaneous and percutaneous electrical stimulation, also promotes enhanced analgesia when used at mixed frequencies rather than when used exclusively at either low or high frequency ${ }^{22,23}$.

The poor postoperative analgesic effect found in DER treated dogs is consistent with previous studies in humans ${ }^{17-19}$ which suggest that the application of electrical stimulus at the peri-incisional dermatomes appears to be most effective for the superficial cutaneous component of postoperative pain, leaving the deep visceral pain component largely intact. It seems likely that electrical nerve stimulation near the incision site mainly stimulates specific afferent nerve fibers instead of triggering endogenous opioid-release mechanisms ${ }^{17}$. However, despite EA and EAD treatments provided better analgesia than DER treatment, the lack of a significantly difference in pain scores among treatments groups at 3, 6, 12 and 24 hours postoperative can easily be explained by the analgesic effect mediated by the supplemental morphine. These findings are consistent with results of other studies ${ }^{24,25}$. The most $(83.3 \%)$ of the DER treated dogs received supplemental morphine at 1 and 3 hours postoperative, while only $33.3 \%$ dogs in EA and EAD treatments were given rescue analgesia.

Anesthesia, surgical trauma and postoperative pain elicit an endocrine response characterized by increased production of catecholamines and cortisol ${ }^{11}$. In the current study, in all treatments groups, serum cortisol did not exceed the reference range ( 0.96 to $6.81 \mathrm{~g} / \mathrm{dl}$ ) at any evaluated time point. However, in all groups, serum cortisol levels were highest at 1 hour postoperative, which agrees with previous studies ${ }^{11,25,26}$. As time progressed, the cortisol concentration returned to baseline values by 24 hours postoperative. There was a poor correlation between pain scores and serum cortisol concentration, corroborating other studies ${ }^{27-29}$. Although, the maximum pain scores and the maximum cortisol levels were observed at first hour after surgery, DER treated dogs had the most pain, but their serum cortisol levels were not higher than the other groups. However, serum cortisol concentration is not pathognomonic for pain ${ }^{25}$, and conditions such as handling, fear, differences in temperament of individual dogs are non-pain related and can stimulate stress responses ${ }^{11}$.

\section{Conclusion}

The results of this study suggest that preoperative application of electrical stimulation at the acupoints ST 36, SP 6 and GB 34 isolated or in combination with electrical stimulation at the dermatomal level of the skin incision reduce the postoperative opioid requirement, resulting in a safe option for analgesia in dogs undergoing ovariohysterectomy.

\section{References}

1. White PF, Li S, Chiu JW. Eletroanalgesia: its role in acute and chronic pain management. Anesth Analg. 2001;92:505-13.

2. Lao L, Bergman S, Langenberg P, Wong RH, Berman B. Efficacy of chinese acupuncture on postoperative oral surgery pain. Oral Surg Oral Med Oral Pathol Oral Radiol Endod. 1995;79(4):423-8.

3. Still J. Anaesthetic and post-anaesthetic effects of placebo, buprenorphine and auricular electro-acupuncture in bitches ovariohysterectomized under halothane anaesthesia. J Altern Complement Med. 1997;16:26-33.

4. Kotani N, Hashimoto H, Yuataka S, Sessler DI, Yoshioka H, Kitayama M, Yasuda T, Matsuki A. Preoperative intradermal acupuncture reduces postoperative pain, nausea and vomiting, analgesic requirement, and sympathoadrenal responses. Anesthesiology. 2001;95:349-56

5. Sim CK, Xu PC, Pua HL, Zhang G, Lee TL. Effects of electroacupuncture on intraoperative and postoperative analgesic requirement. Acupunct Med. 2002;20(2-3):56-65.

6. Laim A, Jaggy A, Forterre F, Doherr MG, Aeschbacher G, Glardon O. Effects of adjunct electroacupuncture on severity of postoperative pain in dogs undergoing hemilaminectomy because of acute thoracolumbar intervertebral disk disease. J Am Vet Med Assoc. 2009;234(9):1141-6.

7. Smith CM, Guralnick MS, Gelfand MM, Jeans ME. The effects of transcutaneous electrical nerve stimulation on post-cesarean pain. Pain. 1986;27(2):181-93. 
8. Chen L, Tang J, White PF, Sloninsky A, Wender RH, Naruse R, Kariger R. The effect of location of transcutaneous eletrical nerve stimulation on postoperative opioid analgesic requirement: acupoint versus nonacupoint stimulation. Anesth Analg. 1998;87:1129-34.

9. Wang B, Tang J, White PF. Effect of intensivity of transcutaneous acupoint eletrical stimulation on the postoperative analgesic requirement. Anesth Analg. 1997;85:406-13.

10. Conzemius MG, Brockman DJ, King LG, Perkowski SZ. Analgesia in dogs after intercostal thoracotomy: a clinical trial comparing intravenous buprenorphine and interpleural bupivacaine. Vet Surg. 1994;23;291-8.

11. Pibarot P, Dupuis J, Grisneaux E, Cuvelliez S, Planté J, Beauregard G, Bonneau NH, Bouffard J, Blais D. Comparison of ketoprofen, oxymorphone, and butorphanol in the treatment of postoperative pain in dogs. J Am Vet Med Assoc. 1997;211:438-44.

12. Almeida RM, Escobar A, Maguilnik S. Comparison of analgesia provided by lidocaine, lidocaine-morphine or lidocaine-tramadol delivered epidurally in dogs following orchiectomy. Vet Anaesth Analg. 2010;37:542-9.

13. Christensen PA, Rotne M, Vedelsdal R, Jensen RH, Jacobsen K, Husted C. Electroacupuncture in anaesthesia for hysterectomy. Br J Anaesth. 1993;71:835-8.

14. Cassu RN, Luna SPL, Clark RM, Kronka SN. Electroacupuncture analgesia in dogs: is there a difference between uni or bilateral stimulation? Vet Anaesth Analg. 2008;35:52-61.

15. Melzack R, Wall PD. Pain mechanisms. A new theory. Science. 1965;150:971-9.

16. Kho HG, Robertson EN. The mechanisms of acupuncture analgesia: review and update. Am J Acup. 1997;25:261-81.

17. Melzack R. Prolonged relief of pain by brief, intense transcutaneous somatic stimulation. Pain. 1975;1:357-73.

18. Melzack R, Wall PD. Acupuncture and transcutaneous electrical nerve stimulation. Postgrad Med J. 1984;60:893-6.

19. Wright M, Mcgrath CJ. Physiologic and analgesic effects of acupuncture in the dog. J Am Vet Med Assoc. 1981;178:502-7.

20. Oliveira R, Prado WA. Anti-hyperalgesic effect of electroacupuncture in a model of post-incision. Braz J Med Biol Res. 2000;33:957-60.

21. Han JS. Acupuncture and endorphins. Neurosci Lett. 2004;361(13):258-61.

22. Ghoname EA, Craig WF, White PF, Ahmed HE, Hamza MA, Gajraj NM. The effect of stimulus frequency on the analgesic response to percutaneous electrical nerve stimulation in patients with chronic low back pain. Anesth Analg. 1999;88:841-6.

23. Hamza MA, Ghoname EA, White PF. Effect of the duration of electrical stimulation on the analgesic response in patients with low back pain. Anesthesiology. 1999;9:1622-7.

24. Carpenter RE, Wilson DV, Evans AT. Evaluation of intraperitoneal and incisional lidocaine or bupivacaine for analgesia following ovariohysterectomy in the dog. Vet Anaesth Analg. 2004;31:46-52.
25. Popilskis S, Kohn DF, Laurent L, Danilo P. Efficacy of epidural morphine versus intravenous morphine for post-thoractotomy pain in dogs. J Vet Anaesth. 1993;20:21-5.

26. Leibetseder EN, Mosing M, Jones RS. A comparison of extradural and intravenous methadone on intraoperative isoflurane and postoperative analgesia requirements in dogs. Vet Anaesth Analg. 2006;33:128-36.

27. Reese CJ, Trotter EJ, Short CE, Erb HN, Barlow LL. Assessing the efficacy of perioperative carprofen administration in dogs undergoing surgical repair of a ruptured cranial cruciate ligament. J Am Anim Hosp Assoc. 2000;36:448-55.

28. Lemke KA, Runyon CL, Horney BS. Effects of preoperative administration of ketoprofen on anesthetic requirements and signs of postoperative pain in dogs undergoing elective ovariohysterectomy. J Am Vet Med Assoc. 2002;221:1268-75.

29. Egger CM, Glerum L, Michelle Haag K, Rohrbach BW. Efficacy and cost-effectiveness of transdermal fentanyl patches for the relief of post-operative pain in dogs after anterior cruciate ligament and pelvic limb repair. Vet Anaesth Analg. 2007;34(3):200-8.

\section{Correspondence:}

\section{Renata Navarro Cassu}

Faculdade de Medicina Veterinária e Ciência Animal-Unoeste

Departamento Cirurgia Veterinária e Anestesiologia

19067-175 Presidente Prudente-SP Brasil

Tel.: (55 18)3229-2077

navarro@unoeste.br

renavarro@uol.com.br

Received: August 16, 2011

Review: October 18, 2011

Accepted: November 21, 2011

Conflict of interest: none

Financial source: FAPESP

${ }^{1}$ Research performed at Veterinary Hospital, Department of Veterinary Surgery and Anestesiology, Scholl of Veterinary Medicine, Universidade do Oeste Paulista (Unoeste), Presidente Prudente-SP, Brazil. 